УДК 347.73+351.9(477)

\author{
Наталія Карлівна Ісаєва, \\ стариий науковий співробітник відділу проблем \\ державного управління та адміністративного права \\ Інституту держави і права ім. В. М. Корецького НАН України, \\ кандидат юридичних наук, дочент
}

\title{
НАПРЯМИ ВДОСКОНАЛЕННЯ ФІНАНСОВОГО КОНТРОЛЮ В УКРӒ̈НІ: ОРГАНІЗАЦІЙНО-ПРАВОВІ ЗАСАДИ
}

Постановка проблеми. Належна організація і правове забезпечення здійснення фінансового контролю в державі завжди $є$ актуальною проблемою для розробок як вчених, так і практиків, оскільки фінансовий контроль $є$ не лише важливою частиною державного контролю, але від його ефективності значною мірою залежить дотримання законності в усіх сферах діяльності держави.

Крім того, фінансовий контроль повинен бути дієвою складовою комплексу антикорупційних заходів, які здійснює держава в сучасний період свого розвитку як одне з найгостріших завдань, без вирішення якого неможлива побудова сучасної демократичної європейської країни.

Причому зазначене стосується організації та правового забезпечення здійснення як державного, так і недержавного фінансового контролю в Україні.

Характеризуючи особливості фінансового контролю, необхідно враховувати, що, в першу чергу, йому притаманні всі головні особливості державного контролю в цілому. Фахівцями державний контроль розглядається як одна з важливих функцій державного управління.

Зокрема, як зазначає О. Ф. Андрійко, контроль $\epsilon$ важливою частиною державного управління і традиційно розглядається як одна із основних його функцій. Він органічно пов'язаний з іншими функціями управління і як стадія, етап присутній при реалізації кожної із них, але вже як допоміжна дія, що спрямована на перевірку попередньо виконаних основних дій і відповідності їх завданням і функції.

Сутність державного контролю як функції управління полягає у аналізі об'єктивної і достовірної інформації щодо ситуації у відповідній сфері, перевірці стану виконання управлінських рішень, покладених завдань та установлених нормативних приписів, нагляді за дотриманням норм і встановлених стандартів [1, с. 5].

Державний контроль стосується всіх сфер діяльності держави. Без належної перевірки всіх владних рішень держави, органів місцевого самоврядування їх посадових осіб, уповноважених на виконання своїх керівних та управлінських обов'язків, без перевірки дотримання виконання вимог та правил, визначених нормативно-правовими актами, $є$ неможливим належне функціонування всіх елементів складного державного механізму.

Основні результати дослідження. Як зазначають В. Б. Авер'янов та О. Ф. Андрійко контроль, як невід'ємна складова управління призначений для підвищення його ефективності і здійснення в межах, визначених правовими нормами. А отже, і сама система державного контролю, як і система його органів, будується у тісному зв'язку із потребами забезпечення державного управління [2, с. 22].

О. Ф. Андрійко справедливо вважає, що аналіз існуючої практики поділу контролю на його види показав, що якогось єдиного установленого правила не існує. В залежності від того, які властивості чи стан якого явища викликають значний інтерес, такий вид контролю чи сукупність видів застосовують для його забезпечення.

Різноманітні види контролю, що на сьогодні існують на практиці, можна класифікувати за:

- суб'єктами, що здійснюють контроль;

- за характером контролю;

- обсягом контрольних повноважень;

- сферами контролю;

- характером відносин суб’єкта контролю з підконтрольними об’єктами та ін. 
Ісаєва Н. К. Напрями вдосконалення фінансового контролю в Україні: організаційно-правові...

Різні види контролю мають свою специфіку, характерні відмінності, що визначаються у завданнях, у способах, формах здійснення контролю. Усі види державного контролю тісно пов'язані між собою, можуть накладатися, перетинатися, доповнювати один одного, здійснюватися у різному об'ємі, з різних позицій та характеру дій [3, с. 9].

Фінансовий контроль визначається різними авторами з урахуванням його особливостей в залежності від суб'єктів, які його здійснюють, об'єктів контролю і певною мірою з урахуванням форм і методів його здійснення.

Достатньо повним $€$ визначення фінансового контролю Л. А. Савченко, яка зазначає, що фінансовий контроль - це діяльність державних органів, недержавних організацій, самих господарюючих суб'єктів чи їх структурних підрозділів, фізичних осіб, наділених відповідними повноваженнями чи правами, що спрямована на забезпечення законності, фінансової дисципліни, раціональності в ході мобілізації, розподілу і використання фінансових ресурсів.

У свою чергу, як вважає цей автор, публічний фінансовий контроль - це регламентована правовими нормами діяльність державних органів, органів місцевого самоврядування, інших публічних суб'єктів і недержавних організацій, господарюючих суб'єктів чи їх структурних підрозділів, фізичних осіб наділених відповідними повноваженнями чи певними правами, що спрямована на забезпечення законності, обгрунтованості під час формування публічних фондів коштів, надходження коштів у відповідні фонди, законності й ефективності їх розподілу, перерозподілу і використання, а також законності, ефективності управління державним та комунальним майном [4, с. 43-44].

3 зазначеним цілком можна погодитись 3 огляду на комплексний підхід до розуміння фінансового контролю водночас 3 диференціацією і розмежуванням конкретних видів фінансового контролю, а саме на: фінансовий контроль державний і недержавний, а також публічний фінансовий контроль, як комплексний вид фінансового контролю.

Органи, які здійснюють фінансовий контроль, складають розгалужену систему органів. По-перше, це органи загальної компетенції: Верховна Рада України, Президент України, Кабінет Міністрів України, а на місцях органи місцевого самоврядування та місцеві державні адміністрації. Конституцією України та чинним законодавством вони наділені достатньо широкими повноваженнями у сфері фінансового контролю. По-друге, це органи спеціальної компетенції, які також можна поділити на дві групи: органи, які здійснюють як керівні, так і контрольні функції у фінансовій сфері, і органи, які здійснюють лише контрольні функції. До першої групи належить Міністерство фінансів України, Державна казначейська служба, Державна фіскальна служба.

3 урахуванням рекомендацій Міжнародного валютного фонду та завдань, визначених Середньостроковим планом пріоритетних дій Уряду до 2020 року, Кабінет Міністрів України схвалив 3 доопрацюванням постанову № 1200 від 18 грудня 2018 р. «Про утворення Державної податкової служби України та Державної митної служби України».

Відповідно до зазначеної постанови Державна податкова служба України та Державна митна служба України створюються шляхом реорганізації Державної фіскальної служби України.

Державна податкова служба $\epsilon$ центральним органом виконавчої влади, діяльність якого спрямовується і координується Кабінетом Міністрів України через міністра фінансів і який реалізує державну податкову політику, державну політику з адміністрування єдиного внеску на державне соціальне страхування, державну політику у сфері боротьби з правопорушеннями під час застосування податкового законодавства, а також законодавства 3 питань сплати єдиного внеску.

Державна митна служба є центральним органом виконавчої влади, діяльність якого спрямовується та координується Кабінетом Міністрів України через міністра фінансів і який реалізує державну митну політику, державну політику у сфері боротьби з правопорушеннями під час застосування митного законодавства.

Державна податкова служба та Державна митна служба $є$ правонаступниками прав та обов'язків реорганізованої Державної фіскальної служби у відповідних сферах діяльності.

Державна фіскальна служба продовжує здійснювати свої повноваження та виконувати функції до завершення здійснення заходів з утворення Державної податкової служби та Державної митної служби [5].

Розмежування податкової і митної служби $є$ цілком виправданим, проте, слід зауважити, що митна сфера має свою особливу специфіку, пов'язану із забезпеченням економічної безпеки держави і здійсненням, насамперед, митного контролю i, як частину цього контролю, фінансового в обсязі, 
який $є$ необхідним для забезпечення ефективності і повноти саме митного контролю. Тому, на наш погляд, більш доцільним було б відновлення в Україні Державного митного комітету України, як окремого державного органу, підпорядкованого безпосередньо Кабінету Міністрів України і координуючого свою діяльність 3 Державною податковою службою і Міністерством фінансів.

До другої групи органів спеціальної компетенції, що здійснюють державний фінансовий контроль, належать органи Державної аудиторської служби, уповноважені Кабінетом Міністрів України, Рахункова палата, яка здійснює від імені Верховної Ради України парламентський контроль. До цієї категорії слід також віднести здійснення внутрішнього контролю та внутрішнього аудиту, який забезпечується відповідно розпорядниками бюджетних коштів та підрозділами внутрішнього аудиту установ.

У цьому контексті обгрунтованою $€$ позиція В. М. Геращука щодо призначення фінансового контролю. Зокрема, він зазначає, що призначення фінансового контролю в тому, що він виконує статистично-аналітичну функцію як у масштабі усієї держави, так і в межах відповідного господарюючого суб'єкта, що дозволяє бачити загальну картину господарювання, прогнозувати, планувати та корегувати господарську, фінансову та іншу діяльність. 3 цієї позиції фінансово-господарський контроль, що проводиться в Україні, класифікується залежно від структур, які його здійснюють, та розподіляється на два види: державний (здійснюється державними органами) та недержавний (здійснюється недержавними утвореннями) [6, с. 87-93].

Органи, які здійснюють державний контроль у сфері фінансової діяльності, мають спільну мету, але кожен із них виконує свої завдання для досягнення цієї мети [7, с. 32].

Тому надзвичайно важливим $є$ забезпечення координації діяльності органів, які здійснюють фінансовий контроль.

Координація фінансового контролю повинна забезпечувати запровадження нових підходів до здійснення фінансового контролю та його дієвості, ефективності, доцільності; створення єдиного правового поля для розвитку системи фінансового контролю, єдиних підходів до проведення спільних і скоординованих контрольних заходів і здійснення інших функцій контролюючими суб'єктами, наприклад, експертно-аналітичної; оптимізацію організаційних структур фінансового контролю; узгодження функцій усіх контролюючих суб'єктів і концентрацію їхніх зусиль на пріоритетних напрямах контролю; мінімальне втручання у фінансову, господарську та іншу діяльність підконтрольних суб'єктів і максимальну ефективність контрольних заходів; підвищення фахового рівня працівників контролюючих суб'єктів. Це потребує розробки відповідного механізму координації фінансового контролю, закріплення його у відповідних нормативно-правових актах $[8$, с. 98].

Водночас справедливим є висновок Л. Попової, що великий обсяг обліково-аналітичної інформації та контрольних процедур, залучення до їх обробки значної техніки обумовлює необхідність розширення сфери діяльності фінансово-господарського контролю і слід забезпечити розподіл праці органів контролю за функціональними принципами. При цьому різнорідна обліково-аналітична інформація про фінансово-господарські операції підприємницьких структур контролюється односторонньо, що не може забезпечити глибоке дослідження всіх сторін їх діяльності.

Висновок. Тому для того, щоб фінансовий контроль мав ефективний вплив на роботу підконтрольних структур, доцільно розширити сферу його діяльності та проводити його об'єднаними зусиллями всіх контролюючих служб державного, відомчого та позавідомчого рівнів, більш чітко з'ясовувати мету і завдання контролю, планувати і координувати його роботу, визначати терміни ії виконання та складати проміжні програми для вирішення окремих завдань [9, с. 121].

При цьому, на наш погляд, загальну координацію здійснення фінансового контролю в державі доцільно покласти на Міністерство фінансів України, в структурі якого необхідно створити відповідний підрозділ та визначити його функціональні обов'язки.

\section{Список використаних джерел}

1. Андрійко О. Ф. Державний контроль: теорія і практика: наукова доповідь. Київ: Ін-т держави і права ім. В. М. Корецького НАН України, 1999.

2. Авер'янов В. Б., Андрійко О. Ф. Виконавча влада і державний контроль. Київ: Ін-т держави і права ім. В. М. Корецького НАН України, 1999.

3. Андійко О. Ф. Державний контроль: теорія і практика: наукова доповідь. Київ: Ін-т держави і права ім. В. М. Корецького НАН України, 1999. 
4. Савченко Л. А. Правові основи фінансового контролю: навч. посібник. Київ: Юрінком Інтер, 2008.

5. Про утворення Державної податкової служби України та Державної митної служби України: постанова Кабінету Міністрів України від 18.12.2018 р. № 1200.

6. Геращук М. Ознаки, функції та система фінансового контролю в Україні // Державне будівництво та місцеве самоврядування. 2002. Вип. 4.

7. Авер'янов В. Б., Андрійко О. Ф. Виконавча влада і державний контроль. Київ: Ін-т держави і права імені В. М. Корецького НАН України, 1999.

8. Савченко Л. А., Зима Д. Л. Правові проблеми координації фінансового контролю. Київ: Вид-во Київського міжнар. ун-ту, 2008.

9. Попова Л. Класифікація фінансово-господарського контролю // Публічне право. 2018. № 1 (29).

\section{References}

1. Andriyko O. F. Derzhavnyi kontrol: teoria i praktyka: nayk. dopovid. Kyiv: In-t derzhavy i prava im. V. M. Korezkogo NAN Ukrainy, 1999.

2. Averianov V. B., Andriyko O. F. Vykonavcha vlada i derzhavnyi kontrol. Kyiv: In-t derzhavy i prava im. V. M. Korezkogo NAN Ukrainy, 1999.

3. Andriyko O. F. Derzhavnyi kontrol: teoria i praktyka: nayk. dopovid. Kyiv: In-t derzhavy i prava im. V. M. Korezkogo NAN Ukrainy, 1999.

4. Savchenko L. A. Pravovi osnovy finansovogo kontrolu: navch. posibnyk. Kyiv: Urinkom Inter. 2008.

5. Pro ytvorenna Derzhavnoi podatkovoi slyzhby Ukrainy ta Derzhavnoi mytnoi slyzhby Ukrainy: postanova Kabinetu Ministriv Ukrainy vid 18.12.2018 r. № 1200.

6. Gerazchyk M. Oznaky, fynkcii ta systema finansovogo kontrolu v Ukrainy // Derzhavne bydivnyctvo ta misceve samovradyvanniy. 2002. Vyp. 4.

7. Averianov V.B., Andriyko O. F. Vykonavcha vlada i derzhavnyi kontrol. Kyiv: In-t derzhavy i prava im. V. M. Korezkogo NAN Ukrainy, 1999.

8. Savchenko L. A., Zyma D. L. Pravovi problemy koordynacii finansovogo kontrolu. Kyiv: Vyd-vo Kyivskogo mizhnar. un-tu, 2008.

9. Popova L. Klasyfikacia finansovo-gospodarskogo kontrolu // Pyblichne pravo. 2018. № 1 (29).

\section{Ісаєва Н. К. Напрями вдосконалення фінансового контролю в Україні: організаційно-правові засади}

У статті розглядаються організація та деякі правові питання фінансового контролю в Україні на сучасному етапі розвитку держави. Характеризується співвідношення та особливості державного контролю та фінансового контролю, їх мета та призначення. Окреслюються особливості реорганізації органів, які здійснюють фінансовий контроль з метою вдосконалення їх діяльності. Звертається увага на необхідність забезпечення координації фінансового контролю та закріплення у нормативно-правових актах відповідних обов’язків державних органів.

Ключові слова: фінансовий контроль, державний контроль, система органів фінансового контролю, координація фінансового контролю.

\section{Isayeva N. K. Areas of improvement of financial control in Ukraine: organizational and legal principles}

The article deals with the organization and some legal issues of financial control in Ukraine at the present stage of state development. The relations and peculiarities of state control and financial control, their goal and destination are described. The features of the reorganization state bodies that carry out financial control are specified with the aim of improving their activities. Attention is drawn to the need to ensure coordination of financial control and consolidation in the regulatory acts of the respective responsibilities of state bodies.

The author stresses that financial control should also be an effective component of the complex of anti-corruption measures implemented by the state in the modern period of its development as one of the most acute tasks, without positive resolving of which it is impossible to construct a modern European country. Moreover, this refers to the organization and legal support for the implementation of both state and non-state financial control in Ukraine.

Taking into account the considerable branching of the system of state bodies that carry out financial control, it is proposed that the general coordination of its implementation be put on the Ministry of Finance of Ukraine, within the structure of which the relevant unit will be created and its functional responsibilities defined.

Key words: financial control, state control, system of financial control bodies, coordination of financial control.

DOI: 10.33.66.3/2524-017X-2019-10-304-307 